\title{
Hubungan kepercayaan diri dengan obesitas pada siswa SMA Negeri 9 Binsus Manado
}

\author{
${ }^{1}$ Clinton N. Polii \\ ${ }^{2}$ Cicilia Pali \\ ${ }^{3}$ Lydia David
}

\author{
${ }^{1}$ Kandidat Skripsi Fakultas Kedokteran Universitas Sam Ratulangi Manado \\ ${ }^{2}$ Bagian Psikologi Fakultas Kedokteran Universitas Sam Ratulangi Manado \\ Email: polii.novanto12247@gmail.com
}

\begin{abstract}
Obesity is a condition where there isan accumulation of excess in body fat, so the weight of a person is far above the normal condition and it is dangerous for health. Obesity or also called as overweight is a problem that is troubling among adolescents. In the group of adolescents, obesity will affect the psychosocial development including self-confidence. Appearance or ideal body shape will foster self-confidence of a person. Self-confidence is a belief of a person that he or she is able to behave as needed to obtain the expected results. This study aims to look at the relationship level of confidence with obesity of the students at SMA Negeri 9 Binsus Manado. This study is using correlational method with cross sectional design. The results showed the level of self confidence for adolescent who has obesity in the highest category are 31 people $(47.6 \%)$. Results on the result $r=-0.224$ and $p=0.080$. Conclusion: This study shows the significant value 0.383 , since the sig value is more than 0.05 , then $\mathrm{H} 0$ is accepted. It means that there is no significant relationship between obesity and self confidence in SMAN 9 Binsus Manado
\end{abstract}

Keywords: obesity, confidence.

\begin{abstract}
Abstrak: Obesitas adalah suatu keadaan dimana terjadi penumpukan lemak tubuh yang berlebih, sehingga berat badan seseorang jauh di atas normal dan dapat membahayakan kesehatan. Obesitas atau disebut juga kegemukan, merupakan suatu masalah yang cukup merisaukan dikalangan remaja. Pada kelompok remaja, obesitas akan berpengaruh pada perkembangan psikososial termasuk kepercayaan diri. Penampilan atau bentuk tubuh yang ideal akan menumbuhkan rasa percaya diri seseorang. Kepercayaan diri merupakan suatu keyakinan yang dimiliki seseorang bahwa dirinya mampu berperilaku seperti yang dibutuhkan untuk memperoleh hasil seperti yang diharapkan. Penelitian ini bertujuan untuk melihat hubungan tingkat kepercayaan diri dengan obesitas pada siswa di SMA Negeri 9 Binsus Manado. Penelitian ini bersifat korelasional dengan rancangan potong lintang. hasil penelitian menunjukkan tingkat kerpecayaan diri pada remaja yang obesitas berada pada kategori tinggi sebanyak 31 orang $(47,6 \%)$. Hasil analisis data diperoleh hasil $r=-0,224$ dan $\mathrm{p}=0,080$. Simpulan: Penelitian ini menunjukkan nilai signifikasi 0,383 , dimana nilai sig lebih dari 0,05 maka $\mathrm{H} 0$ diterima. Hal ini berarti tidak terdapat hubungan yang signifikan antara obesitas dan kepercayaan diri di SMAN 9 Binsus Manado.
\end{abstract}

Kata kunci: obesitas, kepercayaan diri.

Kepercayaan diri merupakan suatu keyakinan yang dimiliki seseorang bahwa dirinya mampu berperilaku seperti yang dibutuhkan untuk memperoleh hasil seperti yang diharapkan. ${ }^{1}$ kurangnya pengenalan dan pemahaman remaja terhadap diri sehingga mengakibatkan penilaian terhadap diri sendiri dan kemampuan kurang cermat 
yang pada akhirnya dapat menimbulakan kurang percaya diri. ${ }^{2}$ Individu yang rasa percaya dirinya rendah akan mengalami hambatan-hambatan dalam hidupnya, baik dalam berinteraksi dengan individu lain maupun dalam pekerjaan. ${ }^{3}$ Selain itu sejumlah peneliti telah menemukan bahwa penampilan fisik merupakan suatu contributor yang sangat berpengaruh pada rasa percaya diri remaja. ${ }^{4}$

Masa remaja adalah masa yang menyenangkan, namun juga masa yang kritis dan sulit, karena merupakan masa transisi atau peralihan dari masa kanakkanak menuju masa dewasa, yang ditandai dengan perubahan aspek fisik, psikis, dan psikososial. ${ }^{5}$ Jika anak sedang dalam masa remaja dan mengalami obesitas dapat menganggu kejiwaan pada anak, yakni sering merasa kurang percaya diri. $^{6}$ Menurut penelitian Bray orang yang mengalami obesitas cenderung lebih sensitif dalam berinteraksi dibanding dengan orang yang tidak mengalami obesitas. ${ }^{7}$ Kasus obesitas menjadi semakin serius mengingat prevalensi obesitas yang semakin meningkat. ${ }^{8}$ Obesitas atau kegemukan adalah suatu keadaan yang terjadi jika kuantitas jaringan lemak tubuh dibandingkan dengan berat badan total lebih besar dari keadaan normalnya, atau suatu keadaan di mana terjadi penumpukan lemak tubuh yang berlebih sehingga berat badan seseorang jauh di atas normal. ${ }^{9}$ Prevalensi obesitas pada anak dan remaja semakin meningkat dari tahun ke tahun baik di dunia, di Asia maupun di Indonesia. Prevalensi obesitas di Indonesia menurut data Riset Kesehatan Dasar tahun 2007, penduduk usia 15 tahun atau lebih adalah 10,3\%, sedangkan Jawa Barat prevalensi berat badan berlebih pada anak usia 6-14 tahun laki-laki 7,4\% dan perempuan 4,6 \%. ${ }^{10}$ Prevalensi obesitas pada remaja di kota Manado tahun 2005 adalah 9,88\%, sedangkan prevalensi remaja obesitas di kota tomohon pada tahun 2010 sebesar 35\%.Tingginya prevalensi obesitas disebabkan oleh pertumbuhan urbanisasi dan perubahan gaya hidup seseorang termasuk pola makan atau asupan energi. ${ }^{11}$

\section{METODE PENELITIAN}

Jenis penelitian ini ialah korelasional dengan desain potong lintang. Penelitian dilakukan pada bulan Oktober-Desember 2015 di SMA Negeri 9 Binsus Manado. Subjek penelitian diambil dari seluruh siswa/i SMA Negeri 9 Binsus Manado yang obesitas dan memenuhi kriteria inklusi dan eksklusi. Jumlah subyek obes sebanyak 65 siswa/i. Pengambilan sampel menggunakan purposive sampling. Analisis data menggunakan teknik korelasi Pearson Product Moment dengan program SPSS 20 for Windows.

\section{HASIL PENELITIAN}

Tabel 1. Distribusi responden berdasarkan obesitas

\begin{tabular}{llccc}
\hline No & Keterangan & IMT & Jumlah & Persentase \\
\hline $\mathbf{1}$ & Obesitas I & $25,0-29 \mathrm{~kg} / \mathrm{m}^{2}$ & 40 Orang & $61.5 \%$ \\
$\mathbf{2}$ & Obesitas II & $\geq 30 \mathrm{~kg} / \mathrm{m}^{2}$ & 25 Orang & $38.5 \%$ \\
Total & & 65 Orang & $100 \%$ \\
\hline
\end{tabular}

Tabel 2. Distribusi responden berdasarkan tingkat kepercayaan diri

\begin{tabular}{llccc}
\hline \multirow{2}{*}{ No } & \multirow{2}{*}{ Kepercayaan Diri } & \multicolumn{2}{c}{ Obesitas } & \multirow{2}{*}{ Total } \\
\cline { 3 - 4 } & & I & II & \\
\hline $\mathbf{1}$ & Rendah & 5 Orang & 5 Orang & 10 Orang \\
$\mathbf{2}$ & Sedang & 19 Orang & 5 Orang & 24 Orang \\
$\mathbf{3}$ & Tinggi & 16 orang & 15 orang & 31 orang \\
Jumlah & 40 Orang & 25 Orang & 65 Orang \\
\hline
\end{tabular}


Tabel 3. Distribusi responden berdasarkan obesitas dan tingkat kepercayaan diri

\begin{tabular}{llccc}
\hline \multirow{2}{*}{ No } & \multirow{2}{*}{ Kepercayaan Diri } & \multicolumn{2}{c}{ Obesitas } & \multirow{2}{*}{ Total } \\
\cline { 3 - 4 } & & I & II & \\
\hline 1 & Rendah & 5 Orang & 5 Orang & 10 Orang \\
2 & Sedang & 19 Orang & 5 Orang & 24 Orang \\
3 & Tinggi & 16 orang & 15 orang & 31 orang \\
Jumlah & 40 Orang & 25 Orang & 65 Orang \\
\hline
\end{tabular}

Tabel 4. Hasil korelasi antar dua variabel

\begin{tabular}{llcc}
\hline & & Obesitas & Kepercayaan Diri \\
\hline \multirow{3}{*}{ Obesitas } & Pearson Correlation & 1 & .110 \\
& Sig. (2-tailed) & & .383 \\
& $\mathrm{~N}$ & 65 & 65 \\
\hline \multirow{3}{*}{ Kepercayaan Diri } & Pearson Correlation & .110 & 1 \\
& Sig. (2-tailed) & .383 & \\
& $\mathrm{~N}$ & 65 & \\
\hline
\end{tabular}

\section{BAHASAN}

Dari data yang diambil dari 65 orang responden berdasarkan obesitas didapatkan berat badan dengan golongan Obesitas I dengan presentase sebesar $61.5 \% \quad(40$ orang) sedangkan berat badan dengan golongan Obesitas II sebesar 38.5\% (25 orang). Responden Paling banyak berada pada Berat Badan dengan Golongan Obesitas I. (Tabel 1) Berdasarkan data mengenai tingkat kepercayaan diri (Tabel 2). Responden dengan kepercayaan diri tinggi sebesar $48,8 \%$ (31 orang). Tingkat kepercayaan diri sedang dengan persentase $36,9 \%$ (24 orang), sedangkan tingkat kepercayaan diri rendah sebesar 15,3\% (10 orang). Responden yang paling banyak berada pada tingkat kepercayaan diri tinggi.

Berdasarkan data mengenai obesitas dan kepercayaan diri (Tabel 3). Pada obesitas I kepercayaan diri sedang sebesar 47,5\% (19 orang), obesitas I kepercayaan diri tinggi sebesar 40\% (16 orang) Pada obesitas golongan I dengan kepercayaan diri rendah sebesar $12,5 \%$ (5 orang) dan pada obesitas golongan II dengan kepercayaan diri tinggi sebesar 60\% (15 orang) pada obesitas golongan II dengan kepercayaan diri rendah sebanyak $20 \%$ (5 orang). dan pada obesitas golongan II dengan kepercayaan diri sedang sebesar
$20 \%$ (5 orang). Responden paling banyak berada pada tingkat obesitas golongan I dengan kepercayaan diri tinggi.

Berdasarkan Hubungan antara obesitas dengan kepercayaan diri yang diukur dengan korelasi rank Pearson (Tabel 4). Didapatlan nilai koefisien korelasi sebesar 0,110 yang menunjukkan hubungan antara obesitas dengan kepercayaan diri memiliki hubungan positif, dan nilai signifikasi $0,383>0,05$ yang menunjukkan tidak ada hubungan yang signifikan. Oleh sebab itu hipotesis ditolak karena tidak terdapat hubungan yang signifikan antara kepercayaan diri dan obesitas.

\section{SIMPULAN}

Daari hasil penelitian dapat disimpulkan bahwa tidak terdapat hubungan bermakna antara obesitas dan kepercayaan diri di SMAN 9 Binsus Manado

\section{DAFTAR PUSTAKA}

1. Febrianto B, Herani I, Supriyono Y. Hubungan kepercayaan diri dengan kemampuan hubungan interpersonal pada anggota UB (UNIVERSITAS 2BRAWIJAYA) FITNESS CENTER. Malang. 2013;4:4.

2. Lestari AF. Usaha pembina dalam 
Polii, Pali, David: Hubungan kepercayaan diri...

menumbuhkan rasa percaya diri pada remaja anak asuh di panti asuhan yatim putri Aisyiyah Serangan Yogyakarta. [Skripsi]. [Yogyakarta]: Universitas Islam Negeri Sunan Kalijaga;2008.

3. Idrus M, Rohmiati A. Hubungan kepercayaan diri remaja dengan pola asuh orang tua etnis jawa. Yogyakarta. 2011;6.1-4.

4. Hamdan. Hubungan antara kepercayaan diri dengan motivasi berprestasi pada siswa SMUN 1 Setu Bekasi. 1 Maret 2009. Available from: http://www.gunadarma.ac.id/library/a rticles/graduate/psychology/2009

5. Wijayanti DN. Analisis faktor penyebab obesitas dan cara mengatasi obesitas pada remaja putri. [Skripsi]. [Semarang]: Universitas Negeri Semarang;2013.

6. Sari GE, Hardjono, Priyatama AN. Perbedaan ketidakpuasan terhadap bentuk tubuh ditinjau dari strategi koping pada remaja wanita Di SMAN 2 Ngawi. 11 Januari 2012. Available from:

http://jurnalwacana.psikologi.fk.uns.a c.id/index.php/wacana/article

7. Sari NA. Hubungan antara dukungan sosial dan kepercayaan diri mahasiswi obesitas. 7 Maret 2004. Available from:

http://repository.uii.ac.id/320/SK/I/0/ 00/000/000768

8. Hi'miyah DA, Martini S. Hubungan antara obesitas dengan osteoporosis studi di Rumah Sakit Husada utama Surabaya. 2013;1:173.

9. Sandjaja, Sudikno. Prevalensi gizi lebih dan obesitas penduduk dewasa di Indonesia. 31 Februari 2005. Available from: http://ejournal.persagi.org/go/index.p $\mathrm{hp} /$ Gizi_Indon/article

10.Rosita I, Marhaeni D, Mutyara K. Konseling gizi Transtheoritical model dalam mengubah perilaku makan dan aktivitas fisik pada remaja overweight dan obesitas. 3 mei 2013. Available from: http://pustaka.unpad.ac.id/wpcontent/uploads/2013/03

11.Rupang I, Opod H, Sinolungan J. Hubungan tingkat kepercayaan diri dengan obesitas pada siswa SMA Rex Mundi Manado. 2013;1:344. 